\title{
sciendo
}

\section{REPRODUCTIVE CYCLE AND SIZE AT FIRST MATURITY IN FEMALES OF BROWN CRAB Callinectes bellicosus (STIMPSON 1859) IN THE SOUTHWESTERN GULF OF CALIFOR- NIA, MEXICO}

\author{
Genaro Diarte-Plata ${ }^{1}$, Ruth Escamilla-Montes ${ }^{{ }^{*}}$, Salvador Granados-Alcantar ${ }^{2}$, Antonio Luna-Gonzalez ${ }^{1}$
}

${ }^{1}$ Instituto Politécnico Nacional. Centro Interdisciplinario de Investigación para el Desarrollo Integral Regional. Unidad Sinaloa. Juan de Dios Bátiz Paredes \# 250, 81101, Guasave, Sinaloa, Mexico

${ }^{2}$ Universidad Autónoma de Occidente. Unidad Los Mochis. Blvd. Macario Gaxiola s/n y Carretera México No. 15, 81223, Los Mochis, Sinaloa, Mexico

*Corresponding Author: ruthescamilla25@hotmail.com

\section{ARTICLE INFO}

Received: 31 October 2020

Accepted: 15 March 2021

\section{Keywords:}

Reproduction

Swimcrabs

Callinectes bellicosus

Size of maturity

Oocytes, Sinaloa

\section{ABSTRACT}

The reproductive cycle of the crustacean family Portunidae on the coast of the Pacific is not well known. Therefore, the reproductive cycle and the size at first maturity of brown crab Callinectes bellicosus and its relationship with environmental factors in the El Colorado Lagoon, Ahome, Sinaloa has been determined. A total of 360 females were collected from March 2012 to March 2013. The gonads were fixed in 10\% formalin, histological cuts were made by the paraffin inclusion method and the hematoxylin and eosin staining technique. The diameter of oocytes was determined by stage. The size at first maturity was estimated by a logistic model. Females showed gametogenic activity during the entire study period. The maturity period was from March to November 2012, with two spawning peaks, in September 2012 and March 2013. Maturity was inversely influenced by temperature $(r=-0.4454, P<0.05)$ and no influence by salinity was observed $(P>0.05)$. The diameter of the oocytes showed significant differences between the development stages of the gonad $(P=0.001)$. The size at first maturity was $11.57 \mathrm{~cm}$ of carapace width for females of C. bellicosus.

Diarte-Plata, G., Escamilla-Montes, R., Granados-Alcantar, S., LunaGonzalez, A. (2021): Reproductive cycle and size at first maturity in females of brown crab Callinectes bellicosus (Stimpson 1859) in the southwestern gulf of California, Mexico. Croatian Journal of Fisheries, 79, 125-135. DOI: 10.2478/cjf-2021-0014. 


\section{INTRODUCTION}

Reproduction is one of the most relevant biological processes that allow us to ensure the continuity of the species (Cobo and Fransozo, 2000). The determination of the reproductive patterns is of great importance in particular for commercially exploited species, as they are useful in the development of conservation mechanisms, allowing the maintenance and management of natural resources (Rodríguez-Dominguez et al., 2012; CisnerosMata et al., 2014; Rodríguez-Félix, 2017).

Reproductive biology studies of marine crustaceans focus on anatomical changes in the spermatheca in the reproductive cycle (Van Engel, 1990), as well as the identification and description of different reproductive tactics used by organisms (sex ratio, size at first maturity, spawning period and spawning areas) in response to habitat characteristics (Bernardo, 1993; Castro-Longoria et al., 2003; Delgado and Defeo, 2004; Delgado and Defeo, 2008; Spivak et al., 2010; Becker et al., 2011; RodríguezDominguez et al., 2012).

Under harsh environmental conditions, energy allocation patterns can change and generate variability in reproductive responses (Gage, 1995; Hassall et al., 2005). This allows us to generate important information for the regulation of the catches of brachyuran crustaceans of commercial importance (Delgado and Defeo, 2004).

In brachyuran crabs, some determinations of the reproduction period are based mainly on the presence of ovigerous females throughout the year, the mating period and the development of gonads (Giese, 1959; Pillay and Ono, 1978; Choy, 1988; Sumpton, 1990; CastañedaFernández de Lara et al., 2015). Within this group is the species Callinectes bellicosus of the family Portunidae; the shape of its abdomen and morphochromatic scales based on changes in gonad coloration have been used to describe the maturation cycles of the species (Williams, 1974; Arzate, 1987; González-Ramírez et al., 1990; CastroLongoria et al., 2003; Rodríguez-Dominguez et al., 2012; Escamilla-Montes et al., 2013; Castañeda-Fernández de Lara et al., 2015).

Callinectes bellicosus, commonly known as brown crab, mainly inhabits coastal lagoons and bays at depths ranging from a few centimeters to $15 \mathrm{~m}$ and is also found in protected marshes with mangrove, muddy and submersible vegetation areas (Williams, 1974; Contreras, 1984). It prefers a temperature range of 17 to $32^{\circ} \mathrm{C}$ and salinities similar to coastal areas in lagoons and estuaries (Paul, 1981). During its development, it is exposed to changes in salinity, because its population migrates to lagoons or estuaries to complete its life cycle, most probably as a strategy for efficient feeding and survival (Arreola-Lizárraga and Hernández-Moreno, 2007).

Several studies mention that the reproductive cycle of $C$. bellicosus is complex, so it is not possible to define a single reproductive behavior in the species, which is influenced by various factors: environmental (temperature, salinity, food availability) and latitudinal (latitudinal differences are known to affect population attributes such as size and age structure, reproduction cycles, recruitment and individual growth in crustaceans) and even aggregations by sex, to occur within the lagoon (Bauer, 1992; CastroLongoria et al., 2003; Rodríguez-Dominguez et al., 2012; Rodriguez-Félix et al., 2015a; Rodriguez-Félix et al., 2015b; Rodríguez-Félix, 2017). The economic importance of C. bellicosus in coastal lagoons (Aguilar et al., 2005), the increase in its commercial catch and in particular the lack of knowledge about the reproductive aspects of this commercially important species of crab in the El Colorado Lagoon, Ahome, Sinaloa (Southeastern Gulf of California), Mexico made the objective of this study to evaluate the reproductive cycle and the size at first maturity of crab $C$. bellicosus.

\section{MATERIAL AND METHODS}

\section{Description of the study area}

The El Colorado Lagoon is a shallow water body of approximately $146 \mathrm{~km}^{2}$ with contributions from the $\mathrm{El}$ Fuerte River and the Colorado and Pascola agricultural drains. It is located in the north of the state of Sinaloa between coordinates $25^{\circ} 39^{\prime}, 25^{\circ} 47^{\prime} \mathrm{N}$ and $109^{\circ} 16^{\prime}, 109^{\circ}$ $24^{\prime} \mathrm{W}$. It is half-closed by Lechuguilla Island to the west. It has a connection to the sea in the southwest which is surrounded by a large number of estuaries and mangroves (Díez-Pérez and Ramirez, 1976) (Fig. 1).

\section{Capture of organisms}

A total of 30 females of $C$. bellicosus were collected on a monthly basis ( $n=360$ ), from March 2012 to March 2013. A total of 5 sampling stations were established. Three lines with crab traps were placed to capture animals (each line of $400 \mathrm{~m}$ in length, $40 \mathrm{crab}$ traps with a diameter of $0.50 \mathrm{~m}$ ) from $6: 00$ to $17: 00 \mathrm{~h}$ and pieces of fish were used as bait (mullet Mugil sp.) A grid sampling system was used. Water temperature values were taken with a digital oximeter (YSI $55^{\circledR}$ ) and the salinity with a manual refractometer (Hanna ${ }^{\circledR}$ 0-100 psu) (Diarte-Plata et al., 2018; Escamilla-Montes et al., 2018).

\section{Biometrics}

From the collected organisms, the carapace width $(\mathrm{CW}, \mathrm{cm})$ was measured from end to end of the lateral spines with a $0.05 \mathrm{~mm}$ precision Vernier caliper (Digital Mitutoyo ${ }^{\circledR} 500$ -197), the total weight (TW, g) was recorded with a digital scale balance (Ohaus ${ }^{\circledast}$ digital scale balance, accuracy of $0.01 \mathrm{~g}$ ) (Rodríguez-Domínguez et al., 2012; Diarte-Plata et al., 2018; Escamilla-Montes et al., 2018).

\section{Histological dissection}

At each sampling, 30 females at different stages of maturation were captured. Gonads were removed, fixed with $10 \%$ formalin and taken to the laboratory where 


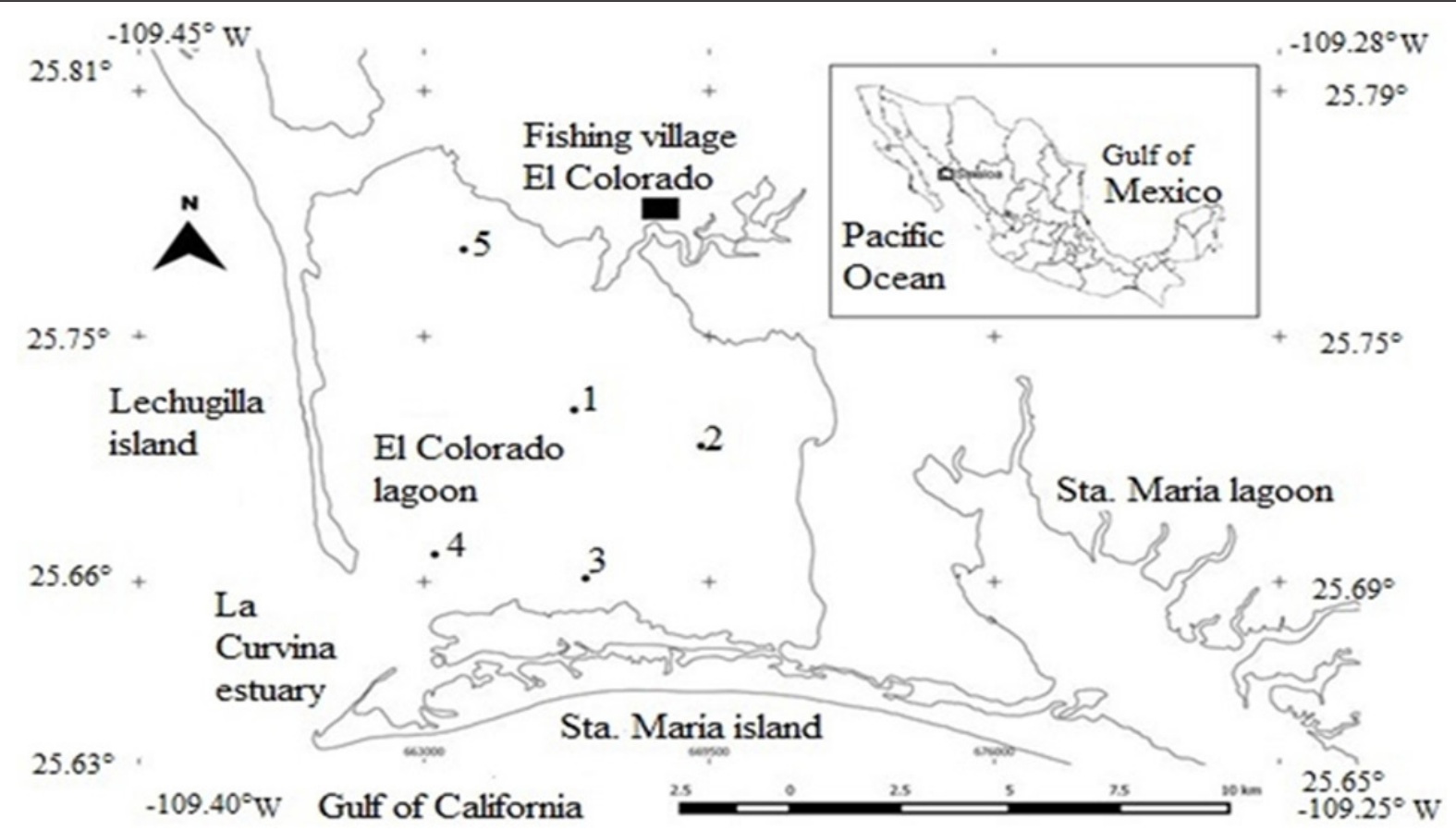

Fig 1. Study area of the El Colorado Lagoon, Ahome, Sinaloa, Mexico

they were dehydrated gradually using an automatic histokinette $\mathrm{BG}^{\otimes}$, through a gradual series of alcohol solutions (alcohol $70 \%$ to absolute alcohol), and clarified with xylene. Subsequently, they were embedded in paraffin, cut with a Leica ${ }^{\circledR}$ microtome $6 \mu \mathrm{m}$ thick and stained using the hematoxylin-eosin technique, and the final assembly was done with synthetic resin (Humason, 1979).

\section{Gonad condition}

Reproductive condition in females was assessed by microscopic gonad staging (optical microscope Nikon ${ }^{\circledR}$ Opti-phot). For the characterization of different phases of development of the gonad, the criteria defined by Castañeda-Fernández de Lara et al. (2015) consisted of dividing the gonadal cycle into 5 phases: immature, development, mature and oocyte spawning; in addition, it was considered the post-spawn stage. Each of the organisms analyzed was classified into one of these phases and the monthly frequencies of each were obtained (Castañeda-Fernández de Lara et al., 2015).

\section{Diameter of oocytes}

The slides were examined with the program for image analysis Image-Pro ${ }^{\circledR} 7.0$ for Window ${ }^{\circledR}$, with which the photographs (Digital camera Nikon ${ }^{\circledR}$ 5MDLS) were obtained and the smaller and larger diameter of the gametes ( $n=30$ per development stage) were estimated in an ocular micrometer of a light field optical microscope Nikon ${ }^{\circledR}$ Opti-phot (Carvalho-Saucedo et al., 2015; Castañeda-Fernández de Lara et al., 2015).

\section{Size at first maturity}

The estimation of the size at first maturity (size at which $\mathrm{CW}_{50 \%}$ of the captured females are in the maturity stage) was done by obtaining the percentage of mature individuals by size class $(1 \mathrm{~cm})$. The curve was adjusted by a logistic model to estimate the parameters and the $\mathrm{CW}_{50 \%}$ using the Curve Expert 1.4 ${ }^{\circledR}$ Program (Salgado-Ugarte et al., 2005; King, 2007):

$$
\text { CW }(50 \%)=1 /(1+\exp (a+b * C W T))
$$

where:

$\mathrm{CW}_{(50 \%)}:$ is the proportion of mature females;

$a$ and $b$ : estimated parameters of the logistic model;

CWT: total shell width $(n=360)$.

The calculation of the size at $50 \%$ maturity was considered as $\mathrm{CWT}_{50 \%}=(-\mathrm{a} / \mathrm{b})$ (King, 2007).

\section{Statistic analysis}

Normality (Kolgomorov-Smirnov) and homoscedasticity (Bartlett) tests were performed to the frequencies of the gonadal development stages, with the purpose of defining the type of statistical parameters. A one-way ANOVA was performed for the temperatures and salinity values in the study period, and also between the diameters of the oocytes in the developmental stages of the gonad. Tukey's post-hoc tests were performed to determine the differences between the mean diameters of the oocytes in the stages of gonadal activity. A Pearson correlation was made between the relative frequencies of the gonadal activity stages versus temperature and salinity, with a significance level of $\alpha=0.05$. The Statistica ${ }^{\circledR} 7.0$ and Excel ${ }^{\circledR} 2013$ packages were used (Sokal and Rohlf, 1995; Zar, 2010; Diarte-Plata, 2016). 


\section{RESULTS}

In the $\mathrm{El}$ Colorado Lagoon, the average annual water temperature was $25 \pm 0.64^{\circ} \mathrm{C}$, the minimum values were recorded in January and March $2013\left(18.4^{\circ} \mathrm{C}\right)$ and the maximum in August $2012\left(31.8^{\circ} \mathrm{C}\right)$. There were significant differences in temperature in the study months $\left(\mathrm{F}_{(11,0.05)}=\right.$ $5.955, P=0.000008)$. The average annual salinity was $35 \pm$ 0.30 psu, with a low level in August and September 2012 (32 psu) and a high one in January 2013 (38 psu). There were significant differences between the study months ( $F$ $(11,0.05)=3.363, \mathrm{P}=0.002116)$.

\section{Biometrics}

\section{CW and TW of female crabs C. bellicosus}

Females showed a range of sizes of 5.0 to $17.1 \mathrm{~cm}$ of carapace width $(\mathrm{CW})$, with a minimum average size in March $2012(8.74 \pm 0.42 \mathrm{~cm})$ and a maximum in December $2012(13.3 \pm 0.34 \mathrm{~cm})$. The recorded range for total weight was 6 to $342 \mathrm{~g}$, with a minimum average weight in September 2012 at $48 \pm 5.23 \mathrm{~g}$ and a maximum in December 2012 at $168.13 \pm 16.47 \mathrm{~g}$ (Table 1).

\section{Gonadal development stages}

Histological characterization of the gonadal development of females of $C$. bellicosus was performed, and the following stages were determined:

Immature

Oogonia proliferation zones (OPZ) and previtellogenic oocytes (PO) in 95\% approximately. The oocytes are basophilic and the nucleus has a peripheral nucleolus (PNC). The average diameter of the oocytes is $58.20 \pm$ $9.76 \mu \mathrm{m}$ (interval, 36.82 to $85.88 \mu \mathrm{m}$ ) (Fig. 2A).

\section{Development}

Presence of previtellogenic oocytes (PO) (15\%) and oocytes in stage I of vitellogenesis (OV-I) occupying $85 \%$ of the area. The oocytes have a slightly visible centric basophil nucleus (N) with a PNC with reserve granules (GR). Delimitation is observed among the oocytes. The average diameter of the oocytes is $304.07 \pm 88.24 \mu \mathrm{m}$ (interval, 170.1 to $514.5 \mu \mathrm{m}$ ) (Fig. 2B).

Table 1. Maximum, minimum and average carapace width $(\mathrm{CW}, \mathrm{cm})$ and total weight $(\mathrm{TW}, \mathrm{g})$ of female crabs of $C$. bellicosus in the El Colorado Lagoon, Ahome, Sinaloa, Mexico

\begin{tabular}{|c|c|c|c|c|c|c|c|c|}
\hline \multirow[b]{3}{*}{ Year } & \multirow[b]{3}{*}{ Month } & \multicolumn{3}{|c|}{ Carapace Width (CW, cm) } & \multicolumn{3}{|c|}{ Total Weight (TW, g) } & \multirow[b]{3}{*}{ n } \\
\hline & & & Average & & & Average & & \\
\hline & & Min. & CW & Max. & Min. & TW & Max. & \\
\hline \multirow[t]{10}{*}{2012} & March & 5.6 & $8.74 \pm 0.1$ & 13.8 & 10 & $67 \pm 0.1$ & 204 & 30 \\
\hline & April & 6.3 & $8.85 \pm 0.5$ & 13.8 & 6 & $48.16 \pm 0.5$ & 140 & 30 \\
\hline & May & 6.3 & $9.49 \pm 0.7$ & 15.0 & 6 & $63.4 \pm 0.2$ & 340 & 30 \\
\hline & June & 6.9 & $10.45 \pm 0.2$ & 15.0 & 18 & $86.92 \pm 0.5$ & 340 & 30 \\
\hline & July & 6.5 & $10.2 \pm 0.7$ & 14.6 & 18 & $70.43 \pm 0.3$ & 210 & 30 \\
\hline & August & 5.0 & $8.8 \pm 0.5$ & 12.0 & 8 & $49.38 \pm 0.3$ & 134 & 30 \\
\hline & September & 8.7 & $10.17 \pm 0.2$ & 15.0 & 20 & $48 \pm 0.2$ & 340 & 30 \\
\hline & October & 8.4 & $10.39 \pm 0.1$ & 13.8 & 20 & $56.92 \pm 0.1$ & 178 & 30 \\
\hline & November & 6.7 & $9.8 \pm 0.6$ & 14.2 & 20 & $73.93 \pm 0.1$ & 240 & 30 \\
\hline & December & 10.2 & $13.3 \pm 0.7$ & 17.1 & 56 & $168.13 \pm 0.8$ & 342 & 30 \\
\hline \multirow[t]{3}{*}{2013} & January & 10.2 & $12.0 \pm 0.2$ & 15.7 & 12.8 & $120.63 \pm 0.7$ & 266 & 30 \\
\hline & February & 5.6 & $10.06 \pm 0.8$ & 13.7 & 12 & $74.29 \pm 0.3$ & 190 & 30 \\
\hline & March & 6.5 & $99.1 \pm 0.1$ & 13.7 & 14 & $81.66 \pm 0.2$ & 188 & 30 \\
\hline
\end{tabular}




\section{Maturity}

Presence of oocytes in stage II of vitellogenesis (OV-II) (95\%), eosinophil with a peripheral nucleus $(\mathrm{N})$ where the well-defined nucleolus is observed and the reserve granules (GR) are easily seen. There are no gaps between the oocytes. The average diameter is $618.6 \pm 183.21 \mu \mathrm{m}$ (interval, 421.9 to $985.2 \mu \mathrm{m}$ ) (Fig. 2C).
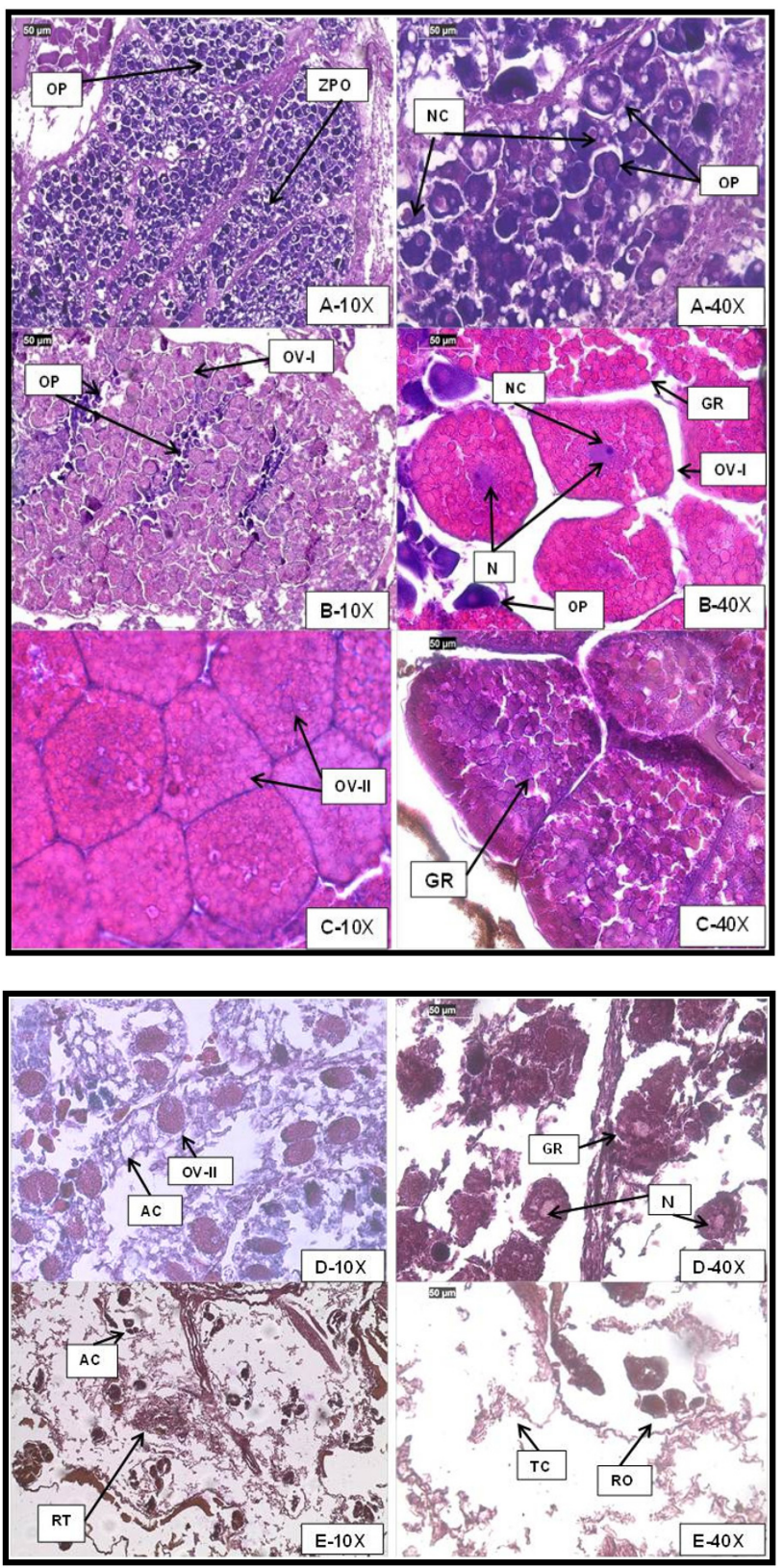

Fig 2. A, B, C, D, E (10X, 40X). Histological stages of gonadal development of crab $C$. bellicosus. A. Immature, B. Development, C. Maturity, D. Spawning, E. Postspawning, AC acini, CT Connective Tissue, N Nucleus, NC Nucleolus, ACM Acini membrane, OPZ Oogonia proliferation zone, PO Previtellogenic oocytes, VO-I Stage I vitellogenic oocytes, VO-II Stage II vitellogenic oocyte, RG. Reserve granules, T.R. Tissue remnants, OR. Oocyte remains.

\section{Spawning}

Minimal presence of eosinophil oocytes in stage II of vitellogenesis (OV-II). In some oocytes the nucleus (N), nucleolus (NC) and reserve granules (GR) are easily observed. The presence of connective tissue remains, in which the empty acini (AC) are preserved. The average diameter is $158.12 \pm 30.67 \mu \mathrm{m}$ (interval, 97.32 to 240.8 $\mu \mathrm{m}$ ) (Fig. 2D).

\section{Post-spawning}

Presence of stage II of vitellogenesis oocytes (OV-II). The connective tissue (CT) with degraded appearance without visible reabsorption of the gonad as well as tissue remains (TR) and eosinophil oocytes (EO), no definite limitations or oocyte acini (AC) appear, which are characteristic in the preceding stages. The average diameter is $225.09 \pm 41.62$ $\mu \mathrm{m}$ (interval, 148.8 to $292.2 \mu \mathrm{m}$ ) (Fig. 2E).

\section{Reproductive cycle}

The reproductive cycle of $C$. bellicosus was described according to the histological analysis. Females showed a gametogenic activity (OPZ) in the five reproductive stages during the study period. Immature organisms appeared in March, April, July, August, October and December 2012 and February 2013. The highest number of crabs was registered in this phase in March 2012 (28.75\%) and February 2013 (33.3\%).

The development phase was presented from March 2012 to February 2013. The highest percentages of organisms in this phase was observed in June 2012 (35.71\%) and January 2013 (38.46\%).

From March to December 2012 and from January to March 2013, females were found in the maturity stage, April (36.84\%) and June (35.71\%) of 2012 being the months with the highest frequencies and with a peak in December 2013 (53.84\%).

The spawning phase occurred from March 2012 to March 2013, with two reproductive peaks in September 2012 with 58.33\% and March 2013 with $64.70 \%$. Females in the post-spawning stage were found from June to August and in November and December 2012, as well as February and March 2013, with the highest percentage in March 2013 (11.76\%) and December 2012 (9.52\%) (Fig. 3).

The immature stage was presented in organisms with an average size of $10.59 \pm 1.10 \mathrm{~cm}$ of $\mathrm{CW}$, the crabs in the development stage registered an average CW of $11.25 \pm$ $2.3 \mathrm{~cm}$. Mature organisms had an average CW of $11.58 \pm$ $0.9 \mathrm{~cm}$, and during spawning the $C W$ was $11.3 \pm 1.5 \mathrm{~cm}$. When relating the stages of gonad activity of the female crab $C$. bellicosus with temperature and salinity, it was observed that when the temperature values were inverse (negative correlation), there were increases in the frequency of organisms in the stages of maturity $(r$ $=-0.5523, t=-2.1973, P<0.05)$, spawning $(r=-0.4453$, $t=-1.6494, P<0.05)$ and post-spawning $(r=-0.5391, t=$ $-2.1231, P<0.05)$. The spawning $(r=0.3108, t=1.0848, P$ $<0.05)$ and post-spawning $(r=0.4304, t=1.5815, P<0.05)$ 
stages showed significant correlations with salinity, not the stage of gonadal maturity $(r=0.5712, t=2.3085, P>$ 0.05) (Fig. 3).

\section{The average diameter of oocytes per reproductive cycle stage}

Oocyte diameter varied from $36.86 \mu \mathrm{m}$ to $985.2 \mu \mathrm{m}$ during the reproductive cycle. The highest average diameter of the oocytes occurred during the maturation phase (618.6 $\pm 83.21 \mu \mathrm{m})$ and the lowest occured in the immature state $(58.20 \pm 9.76 \mu \mathrm{m})$. There were significant differences in the diameter of the oocytes $(F=145.92, P=0.001)$ between the developmental stages of the gonad of $C$. bellicosus in the study period, the immature phase of development being different to the development, maturity, post-spawning phases $(P=0.00017)$ and spawning $(P=0.0037)$ (Fig. 4).

\section{Size at first maturity}

The height at which $50 \%$ of the females of $C$. bellicosus reached maturity $\left(\mathrm{CW}_{50 \%}\right)$ was estimated at $11.57 \pm 1$ $\mathrm{cm} \mathrm{CW}$, with a range of 7.7 to $15.0 \mathrm{~cm} \mathrm{CW}$ for gonadal maturity (Fig. 5). The $\mathrm{CW}_{50 \%}$ parameters for $C$. bellicosus were $a=8.39$ and $b=0.725\left(r^{2}=0.9945\right)$.
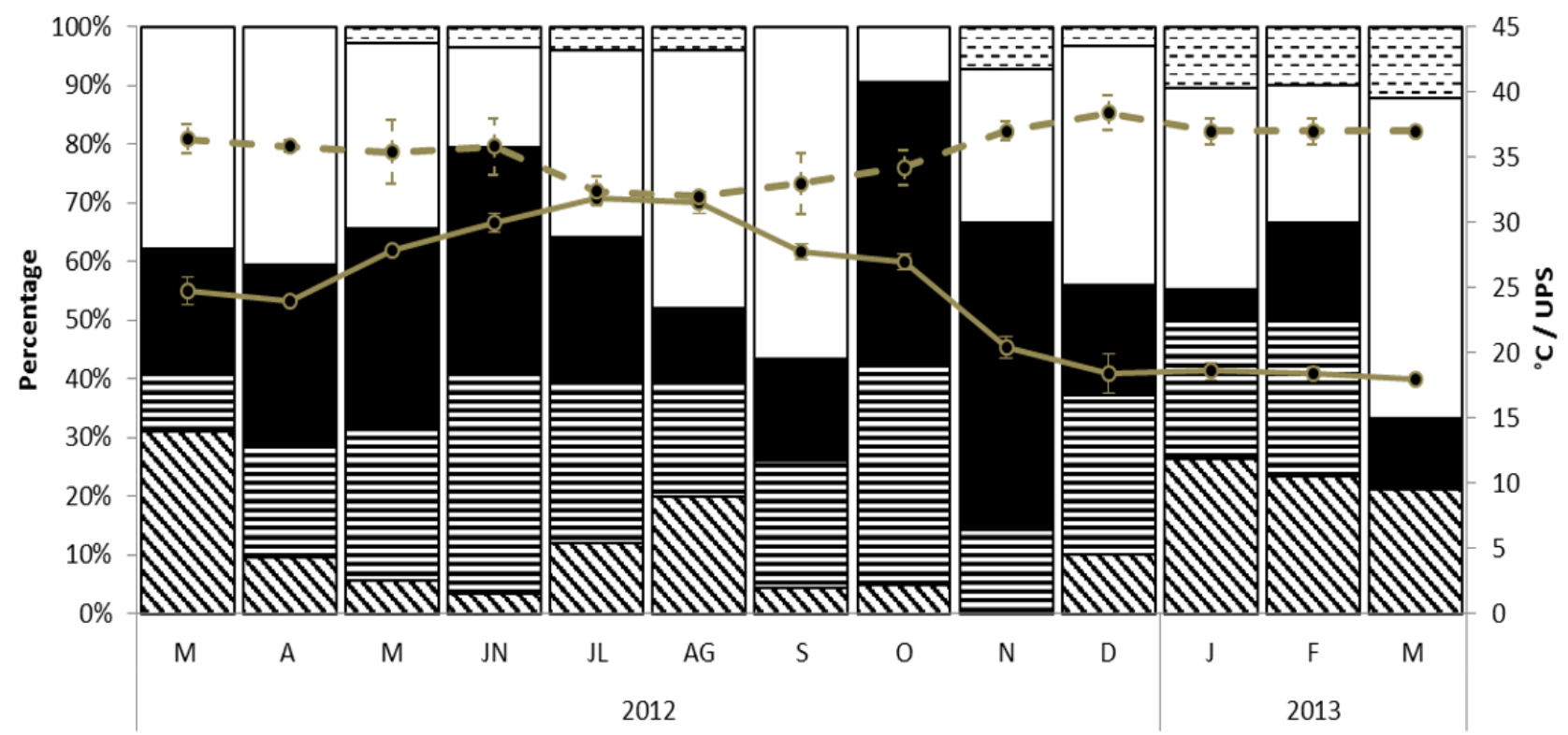

Months
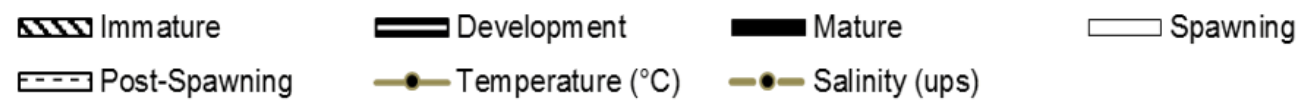

Fig 3. Reproductive cycle of female crabs of $C$. bellicosus in the El Colorado Lagoon, Ahome, Sinaloa, Mexico

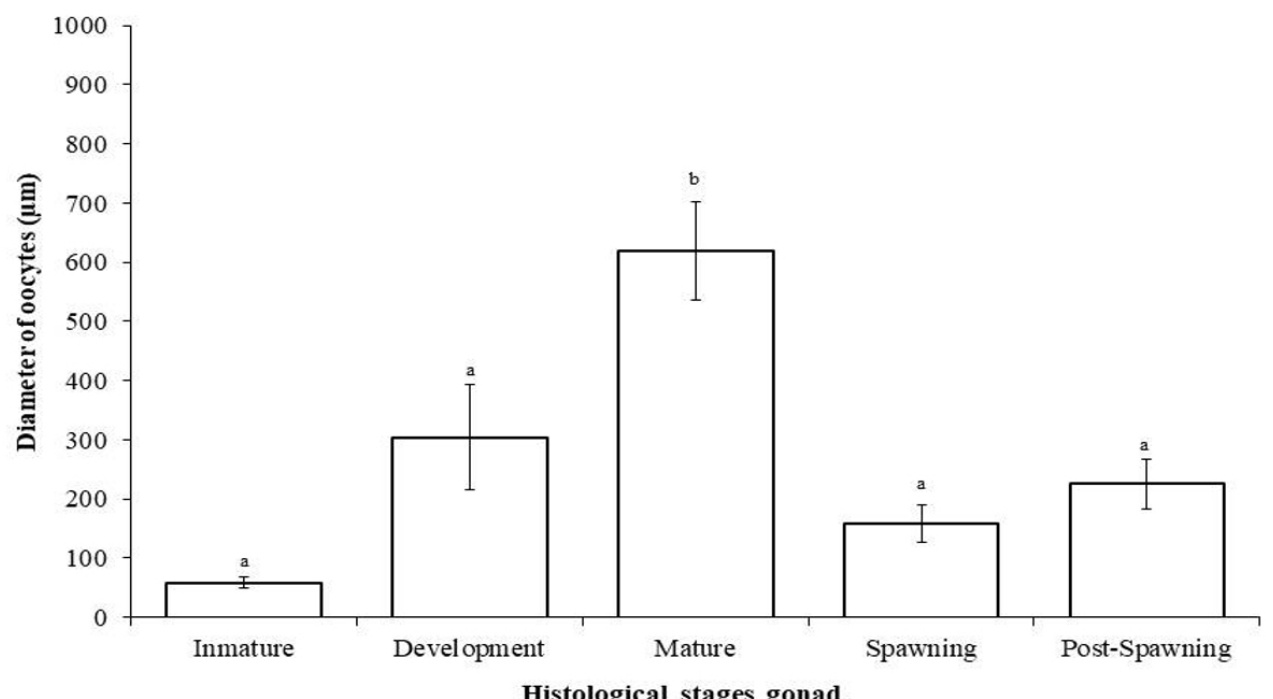

Fig 4. Oocyte diameter of female crabs of $C$. bellicosus in the El Colorado Lagoon, Ahome, Sinaloa, Mexico from March 2012 to March 2013 


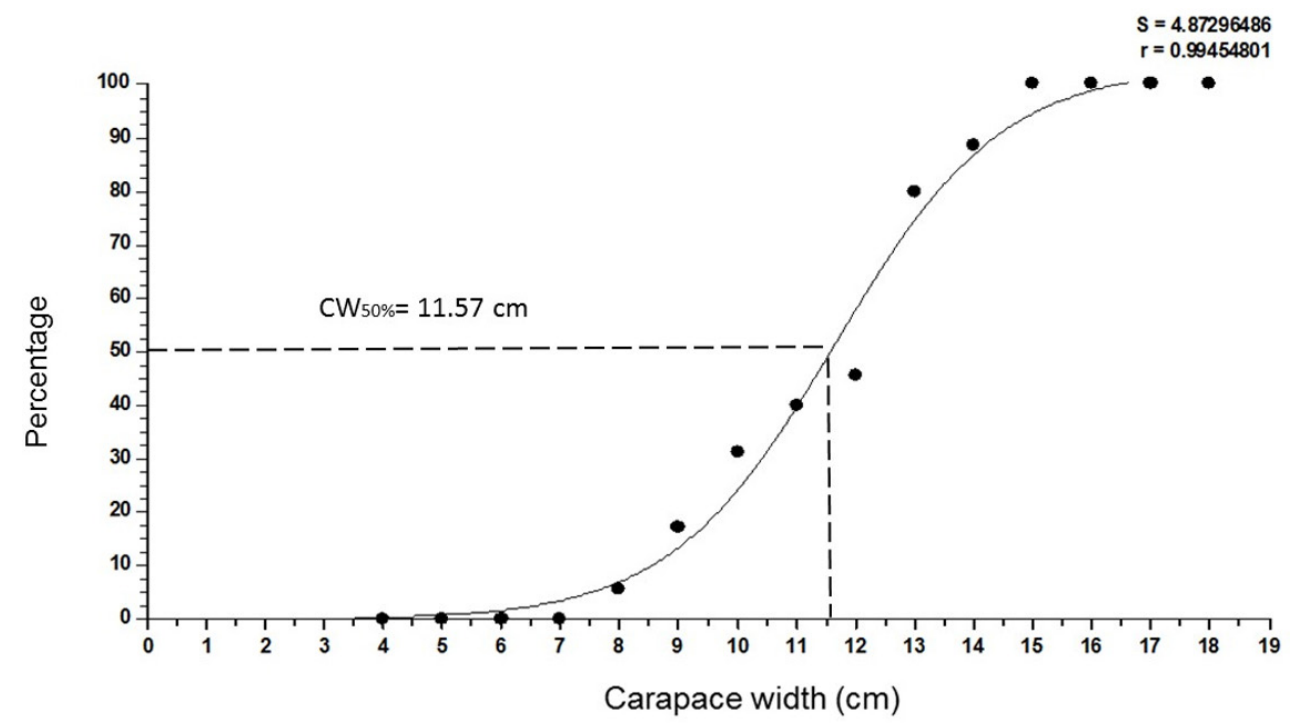

Fig 5. Size at first maturity of crab C. bellicosus in the El Colorado Lagoon, Ahome, Sinaloa, Mexico

\section{DISCUSSION}

The increase in the fishing pressure of $C$. bellicosus generates the need to obtain information on its reproductive behavior, reproductive cycle and size at first maturity, which will provide the guidelines for establishing the minimum catch size, in order to achieve adequate management of these resources. The knowledge of the reproductive dynamics of marine organisms is the most important since this process is responsible for the renewal of the stock or effective fishing (Dumont and D'Incao, 2004).

The reproductive cycle of a Portunid crustacean population includes a series of events, such as activation, growth, development and maturation of gametes, spawning and a resting period (Sastry, 1979; CastañedaFernandez de Lara et al., 2015). In the El Colorado Lagoon, the reproductive cycle of the females of $C$. bellicosus was presented annually and synchronously, with a process of development, maturity and spawning of gametes throughout most of the year (Fig. 3). C. bellicosus showed a seasonal variation in the degree of egg development, according to the season of the year, where the stage of maturity in autumn and winter presented a high percentage of receptive females for mating $(53.84 \%)$, in the same way in spring (36.84\%) and summer (35.71\%). In autumn, the largest proportion of females were spawning. This continued until winter ( $>60 \%)$, so it can be concluded that there is a close relationship between the maturity and spawning phases and seasonal changes in sea surface temperature in the El Colorado Lagoon. This cycle coincides with other species of the genus Callinectes, such as $C$. danae in the Concepción Lagoon in Santa Catarina, Brazil and C. sapidus in Arroyo Valizas in Uruguay, where the reproductive cycle is associated with the seasonal migration from crabs to estuaries. C. bellicosus presented a maturity stage in spring and summer with a high presence of oocytes in previtellogenesis. In the autumn and winter seasons, reproductive organisms were found, some in vitellogenesis. However, this pattern did not coincide with the investigations of Arreola-Lizárraga et al. (2003) and Hernández-Moreno and Arreola-Lizárraga (2007) for C. bellicosus in the Las Guásimas Lagoon, Sonora, Mexico who reported that the breeding season runs from March to September (spring-summer), where the recruitment of juveniles occurred during January and February (winter). Some studies mention that the female crabs of the family Portunidae carry the sperm deposited by the male during intercourse within the seminal sac or spermatheca, and that by nature they only mate once, because the sperm remains viable for up to two years, allowing the female to use it for fertilization and repeated spawning, thus reproducing up to twice per breeding season (PalaciosFest, 2002; Castro-Longoria et al., 2003). On the coasts of the state of Sonora, Mexico, Castro-Longoria et al. (2003) defined two peaks in the period of maximum maturity in C. bellicosus, the first in March with 56\% and the second in July-September (60\%) where the highest percentage of mature females occurred. However, they concluded that the maximum activity of maturation and reproduction of C. bellicosus is from August to September. This coincides with what was observed in this study, where the females of crab C. bellicosus presented two peaks in the gonadal maturity stage and spawn in September 2012 and March 2013, with more than $60 \%$ of analyzed females in these stages. Salazar-Navarro et al. (2002) noted that the copulation of crab $C$. bellicosus was performed from July to September, and the months of inactivity (postspawning) were from October to January, coinciding with what was found in the spawning peaks of $C$. bellicosus in the El Colorado Lagoon.

According to Begon et al. (2006), the life history of an organism is the result of the action of the evolutionary forces and the response of the same to the environment. 
The breeding season of crustaceans usually exhibits great interspecific and intra-specific diversification (Murphy et al., 2007). In tropical regions, they reproduce throughout the year because the environmental conditions are more stable (Sumpton et al., 2003; Trisak et al., 2009; Johnston et al., 2011), as is the case of $C$. bellicosus in the study area where gametogenic activity was constant during the sampling period.

The importance of certain exogenous factors of environmental origin such as temperature, salinity and photoperiod that can act directly or indirectly, favouring or inhibiting sexual differentiation and maturation, has already been mentioned by Castro-Longoria et al. (2003), Rodriguez-Félix et al. (2015b) and RodriguezFélix et al. (2017). For every organism there is an optimal range and values in which its life cycle develops, with a lower energy cost, favoring the somatic and/or gonadal growth (Scelzo and Zúñiga, 1987). In the present study, in the El Colorado Lagoon, the maturity, spawning and post-spawning stages of the gonads in females of crab $C$. bellicosus were significantly correlated with temperature and salinity (except maturity with salinity). This coincides with the hypothesis of Orton (1920) who mentions that the reproductive period of marine species is related to their latitudinal distribution since, for the same species, its broadest breeding season occurs in its southernmost distribution and the shortest occurs in its northernmost distribution. According to this, C. bellicosus presents an annual reproductive cycle in which spawning peaks were recorded in winter, and likewise in spring and summer in the study area. Female crabs of $C$. bellicosus are not the only marine organisms that do not follow the paradigm outlined by Kinne (1970): "The thermal requirements for reproduction are limited to a narrow temperature window separating the growth from the reproductive temperature range" (Rodríguez-Félix et al., 2015a; Rodríguez-Félix et al., 2015b).

While Rodríguez-Félix et al. (2015b) evaluated the effect of sea surface temperature on the maturity size of crab C. bellicosus along a latitudinal gradient on the Eastern coast of the Gulf of California, where they mentioned that contrary to what was observed in other species of crab and shrimp in and out of the Gulf of California, the maturity size of females of $C$. bellicosus was directly proportional to temperature and inversely proportional to latitude. In the El Colorado Lagoon, the spawning condition was influenced inversely by temperature ( $r=$ $-0.4454, \mathrm{P}<0.05$ ). Regarding the relationship of the influence of salinity in the reproductive cycle, it did not show a significant correlation with the maturity of the gonads ( $P>0.05)$. Castro-Longoria et al. (2003) found that brown crab $C$. bellicosus in coastal lagoons in the state of Sonora, Mexico presented a complex degree in its form of reproduction mainly in females, because different stages of development may be found in the reproductive cells, associated with a normal cycle of reproduction and/or maturity within the ovary. These characteristics coincide with what was observed with $C$. bellicosus in the present study in the El Colorado Lagoon, Ahome, Sinaloa.

The quantitative importance of the description of the average egg size during the gonadal maturity process in crustaceans lies in the possibility that females of certain species have to manifest the same pattern of gonadal maturation in terms of the distribution of cells to the interior of the ovary and synchrony of previtellogenic, vitellogenic and mature oocytes (Grant and Tyler, 1983; Eversole, 2001).

The diameter of the oocytes is a good indicator of reproductive activity and has been used in different marine species (Grant and Tyler, 1983; Eversole, 2001). In C. bellicosus, the diameter of the oocytes varied from $36.86 \mu \mathrm{m}$ to $985.2 \mu \mathrm{m}$ over the reproductive cycle. The lowest value occurs in the immature phase and the highest in the mature phase.

The importance of the first functional maturity size of a species lies in statistically determining average size at which organisms are fit to carry out reproduction - morphologically, physiologically and behaviorally which is important in fisheries management. The crabs of the genus Callinectes support important fisheries in several locations in Mexico where they are an artisanal fishing resource that is exploited with great intensity on the Pacific coast (Alvarado-Romero Bonete-Tigre, 2013; Cisneros-Mata, et al., 2014).

In the present study, in the El Colorado Lagoon, the females of $C$. bellicosus reached the height at first maturity $\left(\mathrm{CW}_{50 \%}\right)$ at $11.57 \pm 1 \mathrm{~cm}$ of $\mathrm{CW}$, with a range of 7.7 to $15.0 \mathrm{~cm} \mathrm{CW}$, being greater than reported for the La Choya, La Pinta, Campodónico and El Jagüey Lagoons, that presented a value of $\mathrm{CW}_{50 \%}$ of $11.2 \mathrm{~cm}$, in Yávaros and Agiabampo Bays with $9.7 \mathrm{~cm}$, which may be due to the fact that in higher latitudes of the coasts of the state of Sonora, Mexico the sizes of maturity found for this species are smaller (Rodríguez-Félix et al., 2015; Rodríguez-Félix, 2017). In the Sinaloa Lagoon, the same trend was presented; Rodríguez-Domínguez et al. (2012) reported the sizes at first maturity in females $\left(\mathrm{CW}_{50 \%}\right)$ of $C$. bellicosus, showing a marked segregation according to the size of maturity. The maturity size of the females was $11.50 \mathrm{~cm}$. SalazarNavarro et al. (2008) evaluated the sizes at first maturity in females of Portunidae crabs in the Ceuta, Santa María La Reforma and Navachiste Lagoons on the coast of Sinaloa with sizes of $7.0 \mathrm{~cm}$ for $C$. bellicosus, according to these values recommended raising the minimum size of catch above the size at first maturity to ensure rational exploitation of the resource.

According to the results obtained in this research, the reproductive cycle of brown crab C. bellicosus is complex to delimit a single reproductive behavior of this species, in which various environmental and latitudinal factors have an influence on segregation by sex and age classes within the Laguna El Colorado Sinaloa, Mexico. 


\section{ACKNOWLEDGEMENTS}

We acknowledge the Instituto Politécnico Nacional (IPN), Mexico (SIP20130595, SIP 20150639, SIP20161572, Comisión de Operación y Fomento de Actividades Académicas (COFAA) and Estímulos al Desempeño de los Investigadores (EDI). We are grateful to Dr. Mercedes Guerrero Ruiz for translating the manuscript into English.

\section{REPRODUKTIVNI CIKLUS I VELIČINA ŽENKI PRI PRVOJ ZRELOSTI SMEĐEG RAKA Callinectes bellicosus (STIMPSON, 1859) U JUGOZAPAD- NOM ZALJEVU KALIFORNIJE, MEKSIKO}

\section{SAŽETAK}

Reproduktivni ciklus porodice rakova Portunidae na obali Tihog oceana nije dobro poznat. Stoga je utvrđen reproduktivni ciklus i veličina prve zrelosti smeđeg raka Callinectes bellicosus i njegov odnos s čimbenicima okoliša u laguni El Colorado, Ahome, Sinaloa. Ukupno je prikupljeno 30 ženki od ožujka 2012. do ožujka 2013. Gonade su fiksirane u $10 \%$ formalinu, histološki presijeci napravljeni su pomoću parafina i tehnikom bojenja hematoksilinom i eozinom. Promjer jajnih stanica određen je prema stupnju. Veličina prve zrelosti procijenjena je logističkim modelom. Ženke su pokazale gametogenu aktivnost tijekom cijelog razdoblja istraživanja. Razdoblje zrelosti bilo je od ožujka do studenog 2012., s dva vrhunca mrijesta, u rujnu 2012. i ožujku 2013. Na zrelost je obrnuto utjecala temperatura $(r=-0,4454, p<0,05)$, a nije primijećen utjecaj slanosti $(p>0,05)$. Promjer oocita pokazao je značajne razlike između faza razvoja spolne žlijezde $(P=0,001)$. Veličina prve zrelosti bila je $11,57 \mathrm{~cm}$ širine karapaksa za ženke $C$. bellicosus.

Ključne riječi: razmnožavanje, rakovi plivači, Callinectes bellicosus, veličina zrelosti, oociti, Sinaloa

\section{REFERENCES}

Aguilar, R., Hines, A.H. Wolcott, T.G, Wolcott D.G., Kramer, M.A., Lipcius, R.N. (2005): The timing and route of movent and migration of post-copulatory female blue crabs, Callinectes sapidus Rathbun, from the upper Chesapeake, Bay. Journal of Experimental Marine Biology and Ecology, 319, 117-128.

Alvarado-Romero, M. A., Bonete-Tigre, R. A. (2013): Estudio de factibilidad para la creación de una planta procesadora de cangrejo (Ucides occidentalis) y de jaiba azul (Callinectes sapidus) en la cooperativa 6 de Julio del cantón naranjal. Tesis de Licenciatura. Universidad Estatal de Milagro, Milagro, Ecuador. 235 p.

Arreola-Lizárraga, J.A., Hernández-Moreno L.G., Hernández-Vázquez, S., Flores-Verdugo, J., Lechuga
Devezé, C., Ortega-Rubio, A.A. (2003): Ecology of Callinectes arcuatus and C. bellicosus (Decapoda; Portunidae) in a coastal lagoon of Northwest Mexico. Crustaceana, 76 (6), 651-664.

Arreola-Lizárraga, J.A., Hernández-Moreno, L. G. (2007): Estructura de tallas y crecimiento de los cangrejos Callinectes arcuatus y C. bellicosus (Decapoda: Portunidae) en la laguna costera Las Guásimas, México. Revista de Biología Tropical, 55, 1, 225-233.

Arzate, A. E. (1987): Sinopsis de la investigación biológico pesquera de las jaibas Callinectes sapidus y Callinectes rathbunae en el noroeste del Golfo de México, 19851986. CRIP-Tampico, Tamaulipas, México. II Reunión Indicativa de Actualización de pesca.

Bauer, R. T. (1992). Testing generalizations about latitudinal variation in reproduction and recruitment patterns with sicyoniid and caridean shrimp species. Invertebrate Reproduction and Development, 22, 193202.

Becker, C., Brandis, D., Storch, V. (2011): Morphology of the Female Reproductive System of European Pea Crabs (Crustacea, Decapoda, Brachyura, Pinnotheridae). Journal of Morphology, 272, 12-26.

Begon, M., Harper, J. L., Townsend, C. R. (2006): Ecology: From individuals to ecosystems. 40 ed. Oxford: Blackwell Publishing, $759 \mathrm{p}$.

Bernardo, J. (1993): Determinants of maturation in animals. Trends in Ecology and Evolution, 8, 166-173.

Carvalho-Saucedo, L., Ramírez-Santiago, C., Pérez, C. (2015): Histological description of gonadal development of females and males of Callinectes sapidus Rathbun 1896 (Decapoda: Portunidae). Zoological Science, 32, 2, 188-194.

Castañeda-Fernández de Lara, V., Carvalho-Saucedo, L., García-Borbón, J.A., Gómez-Rojo, C.J. (2015): Validación histológica de una escala morfocromática de maduración gonadal para la jaiba verde, Callinectes bellicosus. Ciencia Pesquera, 23, 43-52.

Castro-Longoria, R., Ramos-Paredes, J., MontemayorLópez, G., Jiménez-Rodríguez, J. (2003): Estudio de la Biología Reproductiva del Recurso Jaiba Callinectes bellicosus, de la Costa del Estado de Sonora. Informe Técnico de la Universidad de Sonora-Instituto Nacional de la Pesca. Hermosillo, México, 48p

Choy, S. C. (1988): Reproductive biology of Liocarcinus puber and Liocarcinus holsatus (Decapoda, Brachyura, Portunidae) from the Gower Peninsula, South Wales. Marine Ecology, 9, 3, 227-241.

Cisneros-Mata, M.A., Ramírez-Félix, E., García-Borbón, J., Castañeda-Fernández de Lara, V., Labastida-Che, C., Gómez Rojo, C., Madrid-Vera, J. (2014): Pesca de jaiba en el litoral del Pacifico mexicano. Instituto Nacional de Pesca, $86 \mathrm{p}$.

Cobo, V.J., Fransozo, A. (2000) : Fecundity and reproduction period of the red mangrove crab Goniopsis cruentata (Brachyura, Grapsidae) São Paulo State, Brazil. p. 527533. In Klein, J.C.V., Schram, F.R. (Eds.), Crustacean 
Issues, The Biodiversity Crisis and Crustacea, Vol.12, Rotterdam, A.A. Balkema.

Contreras, R. (1984): Análisis de la población de Callinectes spp. (Decapoda: Portunidae) en el sector occidental de la laguna de Términos, Campeche, México. Mem. VII Congreso Nacional de Zoología. Universidad Nacional Autónoma de México. Xalapa Veracruz, México, 15-20 pp.

Delgado, E., Defeo, O. (2008): Reproductive plasticity in mole crabs, Emerita brasiliensis, in sandy beaches with contrasting morphodynamics. Marine Biology, 153, 6, 1065-1074.

Delgado, E., Defeo, O. (2004): A complex sexual cycle in sandy beaches: The reproductive strategy of Emerita brasiliensis (Decapoda: Anomura). Journal of the Marine Biological Association of United Kingdom, 86, 361-368.

Diarte-Plata, G. (2016): Aspectos poblacionales de las jaibas del género Callinectes (Decapoda: Portunidae) en la Laguna El Colorado, Ahome, Sinaloa, México. PhD Thesis, Universidad Autónoma de Baja California Sur, $198 \mathrm{p}$.

Diarte-Plata, G., Escamilla-Montes, R., Ruíz-Verdugo, C.A. (2014): Estructura de tallas y relaciones morfométricas de Callinectes arcuatus (Portunidae) en El Colorado, Ahome, Sinaloa, México. El Bohío Boletín Electrónico, 4, 3, 34-39.

Diarte-Plata, G., Escamilla-Montes, R., Ruiz-Verdugo, C.A., Luna-González A., De La Cruz-Agüero, G., GranadosAlcantar, S., Vázquez-López, H., Fierro-Coronado, J.A. (2018): The growth of Callinectes arcuatus (Ordway, 1863) in the El Colorado Lagoon, Ahome, Sinaloa, Mexico. Latin American Journal Aquatic Research, 46, 5, 1041-1054.

Díez-Pérez, J.F. Ramírez, G.(1976): Estudio de las bahías de Ohuira y Topolobampo mediante Landsat. Congreso Nacional de Fotometría, Fotointerpretación y Geodesia. S.R.H.

Dumont, L.F., D'incao, F. (2004): Estágios de desenvolvimento gonadal de fêmeas do camarãobarbaruça (Artemesia longinaris - Decapoda: Penaeidae). Iheringia, Serie Zoologica, 94, 4, 389-393.

Escamilla-Montes, R., De la Cruz-Agüero, G., VillalejoFuerte, M. T., Diarte-Plata. G. (2013): Fecundidad de Callinectes arcuatus (Ordway, 1863) y C. bellicosus (Stimpson, 1859) (Decapoda: Brachyura: Portunidae) en la Ensenada de La Paz, Golfo de California, México. Universidad y Ciencia-Trópico Húmedo, 29, 1, 53- 61.

Escamilla-Montes, R., Diarte-Plata, G., Ruíz-Verdugo, C.A., Granados-Alcantar, S., Luna-González, A., VázquezLópez, H., Fierro-Coronado, J.A., De la Cruz-Agüero, G., Villalejo-Fuerte, M.T. (2018): Patrones de crecimiento y proporción de sexos de la jaiba Callinectes bellicosus (Decapoda: Portunidae). Hidrobiológica, 28, 3, 301311.

Eversole, A. (2001): Reproduction in Mercenaria mercenaria. In Kraeuter, J. Castagna M. (Eds.). Biology of the Hard Clam. Elsevier Science B.V. Netherlands, 221-260 pp.

Gage, M.J.G. (1995). Continues variation in reproductive strategy as an adaptative response to population density in the morth Piodia mierpunculla. Proceedings of the Royal Society of London B, 261, 25-30.

Giese, A.C. (1959): Comparative physiology: Annual reproductive cycles of marine invertebrates. Animal Review of Physiology, 21, 547-576.

González-Ramírez, P. G., García-Domínguez, F., Félix-Pico, E. (1990): Estudio biológico pesquero de las jaibas Callinectes bellicosus Stimpson y C. arcuatus Ordway de Bahía Magdalena, B.C.S. Informe de Proyecto CONACYT. Ref.: P220CCOR 881063. 7 p.

Grant, A., Tyler, P. (1983): The analysis of data in studies of invertebrate reproduction. II. The analysis of oocytes size/frequency data, and comparation of different types of data. International Journal of Invertebrates Reproduction, 6, 271-283.

Hassall, M., Helden, A., Goldson, A., Grant, A. (2005). Ecotypic differentiation and phenotypic plasticity in reproductive traits of Armadillidium vulgare (Isopoda: Oniscidea). Oecologia, 143, 51-60.

Hernández-Moreno, L., Arreola-Lizárraga, J. (2007): Estructura de tallas y crecimiento de los cangrejos Callinectes arcuatus y $C$. bellicosus (Decapoda: Portunidae) en la laguna costera Las Guásimas, México. Revista de Biología Tropical, 55, 1, 225-233.

Humason, G. L. (1979): Animal Tissue Techniques. Cuarta Edición. W. H. Freeman and Co. San Francisco, 629 p.

Johnston, D., Harris, D. Caputi, N., Thomson, A. (2011): Decline of a blue swimmer crab (Portunus pelagicus) fishery in Western Australia-History, contributing factors and future management strategy. Fisheries Research, 109, 119-130.

King, M. (2007): Fisheries Biology, Assessment and Management. Wiley-Blackwell. Oxford, UK, 400 p.

Kinne, O. (1970): Maine Ecology. A comprehensive, integrated treatise on life in oceans and coastal waters. Vol. 1 Environmental factors. John Wiley and Sons, New York, NY.

Murphy, M.D., Mc Millen-Jackson, A.L., Mahmoundi, B. (2007): A stock assessment for blue crab, Callinectes sapidus, in Florida waters Florida Fish and Wildlife Commissions, Florida, 1-90 pp.

Orton, J.H. (1920): Sea-temperature, breeding and distribution in marine animals. Journal Marine Biology Association United Kingdom, 12, 339-366.

Palacios-Fest, M.R. (2002): La Jaiba: Biología y Manejo. Primera Edición. AGT Editor, S. A. México, D. F. 152 p.

Paul, R.G.K. (1981): Natural diet feeding and predatory activity of crabs Callinectes arcuatus and $C$. toxotes (Decapoda, Brachyura, Portunidae). Marine Ecology Progress Series, 6, 71-99.

Pillay, K.K., and Ono, Y. (1978): The breeding cycles of two species of Grapsidae crabs (Crustacea, Decapoda) from the north coast of Kyushu, Japan. Marine Biology, 45, 
237-248.

Rodríguez-Domínguez, G., Castillo-Vargasmachuca, S., Castillo-Vargasmachuca R., Aragón-Noriega, A. (2012): Estimation of individual growth parameters of the brown crab Callinectes bellicosus (Brachyura, Portunidae) using a multi-model approach. Crustaceana, 85, 55-69.

Rodríguez-Félix, D. (2017): Análisis de la estructura poblacional de la jaiba café (Callinectes bellicosus) en la costa de Sonora y sus implicaciones en el manejo. PhD Thesis. Centro de Investigaciones Biológicas del Noroeste, S.C.

Rodríguez-Félix, D., Cisneros-Mata, M.Á., Aragón Noriega, E.A. (2015b): Variability of size at maturity of the warrior swimming crab, Callinectes bellicosus (Stimpson, 1859) (Brachyura, Portunidae), along a latitudinal gradient in the Gulf of California. Crustaceana, 88, 9, 979-989.

Rodríguez-Félix, D., Cisneros-Mata, M.Á., Aragón Noriega, E.A., Arreola-Lizárraga. J.A. (2015a): Talla de primera madurez de jaiba café Callinectes bellicosus en cinco zonas del Golfo de California. Ciencia Pesquera, 23, 5-14.

Salazar-Navarro, I., Macías-Sánchez, V., Ramos-González, A. (2002): Estado que Guarda la pesquería de jaiba Callinectes spp. En las Bahías de Topolobampo y Navachiste, Sinaloa, Periodo febrero a octubre de 1999. In Manejo de Recursos Pesqueros. Reunión Temática Nacional. Morán-Angulo, R.E, Bravo-Mercado, M.T. Santos-Guzmán, S., Ramírez-Zavala, J.R. (Eds.). Universidad Autónoma de Sinaloa, México. 463 p.

Salgado-Ugarte, I.H., Gómez-Márquez, J.L., PeñaMendoza, B. (2005): Métodos actualizados para análisis de datos Biológico-Pesqueros. Universidad Nacional Autónoma de México. Facultad de Estudios Superiores Zaragoza. Primera Edición. México, D. F., México. 240 p

Sastry, (1983): Ecological aspect of reproduction. In Vernberg, F.J., Vernberg, W.B. (Eds). The biology of Crustacea: environment adaptions. Academic Press, New York, NY, 179-270 pp.
Scelzo, A. M. Zúñiga, O. (1987). Consumo de oxígeno en el camarón Penaeus brasiliensis (Decapoda: Penaeidae) en relación a la salinidad y la temperatura. Memoria de la Sociedad de Ciencias Naturales La Salle, 47, 127-128, 201-216.

Sokal, R.R., Rohlf, F.J. (1995): Biometry: The Principles and Practice of Statistics in Biological Research. $3^{\text {rd }}$ Edition, W.H. Freeman and Co., New York.

Spivak, E.D., Arévalo, E., Cuesta, J.A., González-Gordillo, J.I. (2010): Population structure and reproductive biology of the stonr crab Xantho poresa (Crustacea: Decapoda: Xanthidae) in the Corrales de Rota (southwestern Spain) a human-modified intertidal fishing area. Journal of the Marine Biological Association of the United Kingdom, 90, 2, 323-334.

Sumpton, W. D. (1990). Morphometric growth and fisheries biology of the crab Charybdis natator (Herbst) in Moreton Bay, Australia. (Decapoda, Brachyura). Crustaceana, 59, 2, 113-120.

Sumpton, W., Gaddes, S., Mclennan, M., Campbell, M., Tonks, M., Good, N., Hadedoorn, W., Skilleter, A. (2003): Fisheries biology and assessment of the blue swimcrab (Portunus pelagicus) in Queensland. Project No. 98/117, Departament of Primary Industries, Queensland Government, 1-156 pp.

Trisak, J., Soasung, H., Wongkaew, P. (2009): Seasonal variations in catches and effort stove a small-scale swimming crab trap fishery in the Eastern Gulf of Thailand. Songklanakarin Journal of Science Technology, 31, 4, 373-380.

Van Engel, W.A. (1990): Development of the reproductively functional form in the male blue crab, Callinectes sapidus. Bulletin of Marine Science, 46, 1, 13-22

Williams, A.B. (1974): The swimming crabs of the genus Callinectes. Fishery Bulletin, 72, 3, 685-798.

Zar, J. H. (2010): Biostatistical analysis. Prentice Hall, New Jersey: Prentice Hall, 662 p. 